Original Research Paper

\title{
In vitro Rumen Fermentability of the Pelleted Feed Containing Water Spinach (Ipomoea aquatica)
}

\author{
${ }^{1}$ Himmatul Hasanah, ${ }^{2}$ Eko Pangestu, ${ }^{3}$ Ali Agus and ${ }^{2}$ Joelal Achmadi \\ ${ }^{1}$ Department of Biology, Faculty of Mathematic and Natural Science, Yogyakarta State University, Yogyakarta, Indonesia \\ ${ }^{2}$ Faculty of Animal and Agricultural Sciences, Diponegoro University, Semarang, Indonesia \\ ${ }^{3}$ Faculty of Animal Science, Gadjah Mada University, Yogyakarta, Indonesia
}

\author{
Article history \\ Received: 14-01-2020 \\ Revised: 28-02-2020 \\ Accepted: 05-03-2020 \\ Corresponding Author: \\ Joelal Achmadi \\ Faculty of Agriculture and \\ Animal Sciences, Diponegoro \\ University, Semarang, \\ Indonesia \\ Email: jachmadi@gmail.com
}

\begin{abstract}
An in vitro technique based on two stages of batch culture was used to clarify fermentability and digestibility of pellet feed containing water spinach (Ipomoea aquatica). The portion of Pennisetum purpureum in the pellet feed was substituted with Ipomoea aquatica at respective levels of $0 \%$ (T1), 20\% (T2), 40\% (T3) and 60\% (T4). The treatments were allocated in a completely randomized design with 5 replicates of each. The results showed that the substitution of water spinach in pellet did not effect on $\mathrm{pH}$, ammonia $\left(\mathrm{NH}_{3}\right)$, enzyme protein and microbial protein. Volatile Fatty Acids (VFA), acetate (C2), propionate $(\mathrm{C} 3)$, butyrate $(\mathrm{C} 4)$, methane $\left(\mathrm{CH}_{4}\right)$ and carbon dioxide $\left(\mathrm{CO}_{2}\right)$ were decreased $(p<0.05)$ by water spinach substitution level in the treatments. The ratios of $\mathrm{C} 2$ : $\mathrm{C} 3$ were increased $(P<0.05)$ in both of $\mathrm{T} 3$ and T4. The increasing water spinach substitution level enhanced $(p<0.05)$ dry matter digestibility and organic matter digestibility but crude fiber digestibility was unaffected. In conclusion, substitution of Pennisetum purpureum with Ipomoea aquatica at the level of $20 \%$ may be the best fiber source for ruminant diet.
\end{abstract}

Keywords: Digestibility, Fermentation, Water Spinach, In vitro

\section{Introduction}

The quality of forage is one of the factors affecting feed consumption, nutrient utilization and ruminant products. In the tropical countries such as Indonesia, the low quality of forage (contains high level of indigestible fibre) has been a common problems. The latter condition may lead to less efficiency of nutrient utilization resulting in the decrease of ruminant productivity. Therefore, alternative forage with high nutrient content is needed in the hope that it can be maximally utilized by ruminants.

Water spinach (Ipomoea aquatica) is an herbaceous aquatic or semi-aquatic perennial plant of the tropics and subtropics that may be exploited as a fibre source. In Indonesia, the area of water spinach plantation reaches 47,805 ha, with production about 276,976 tons or 5.79 tons per ha (SI, 2017). Some study results suggest that water spinach has a potency as forage for ruminants based on its nutrient content. The study by Khamparn and Preston (2006), Opene et al. (2018) and Umar et al. (2007) showed that water spinach contains crude protein ranging from 5.18$24.6 \%$, fibre $13-17.67 \%$, dry matter $10.3 \%$ and organic matter $87.6 \%$. With regard to the crude protein content, water spinach has been noted to have greater solubility of crude protein and thereby improving the $\mathrm{N}$ utilization by animals (Silivong and Preston, 2016).

In general, forage with high fiber content is marginally utilized by ruminants so it may need a technology for degrading fiber such as pelleting technology. Bertipaglia et al. (2010) and Oyaniran et al. (2018) reported that pelleting break downs the cell wall of forage (cellulose, hemicellulose and lignin) so that it will be easier to be degraded by microbes in the rumen. In the present study, water spinach was mixed with other feedstuffs before being pelleted. To best of our knowledge, the study on the pelleted feed containing water spinach is still scarce. Therefore, the objective of this present study was to evaluate the in vitro rumen ferment ability and digestibility of pelleted feed containing water spinach. 


\section{Materials and Methods}

\section{Experimental Diet and in vitro Test}

Pennisetum purpureum cv Mott grass was cultivated in Sleman Yogyakarta and harvested at 60 days. Concentrate feed was purchased from local feed supplier and water spinach was purchased from the local market in Yogyakarta, Indonesia. Pennisetum purpureum cv Mott grass and water spinach were sundried and ground before being mixed with concentrate. The mixture was then subsequently pelleted. The composition and nutrient contents of the feedstuffs used to formulate pelleted feed are presented in Table 1. The study consisted of four treatments, i.e., T1: Control or pelleted feed containing no water spinach, T2: Pelleted feed containing $20 \%$ of water spinach, T3: Pelleted feed containing $40 \%$ of water spinach and T4: Pelleted feed containing $60 \%$ of water spinach. Treatments were allocated according to a completely randomized design with 5 replicates in each treatment. The feed ingredient and nutrient composition of pelleted feed are shown in Table 2.

\section{In vitro Fermentation}

A two stages of culture batch was used in the in vitro technique. In first stage, sample of diet was incubated in rumen liquid anaerobically for $48 \mathrm{~h}$ (Menke and Steinngas, 1988). A buffer solution was also added in a ratio of $2: 1$ $(\mathrm{v} / \mathrm{v})$ with rumen liquid. The sample residue from first stage was then incubated in pepsin $+\mathrm{HCl}$ mixture for $72 \mathrm{~h}$ in the second stage (Tilley and Terry, 1963). The rumen liquid was obtained from fistulated cows fed on a diet containing $60 \%$ grass and $40 \%$ concentrate feed. The first and second stages were subjected for studying feed rumen fermentability and nutrient digestibility, respevtively. Each dietary treatment was tested with 5 replicates.

\section{Sampling and Analysis}

After $48 \mathrm{~h}$ of fermentation process on Menke and Steinngas method, $\mathrm{pH}$ of the samples were immediately measured and then centrifuged $(3,000$ $\times g, 15 \mathrm{~min} 4^{\circ} \mathrm{C}$ ). The filtrate was divided into 2 parts, one part was stored at $-20^{\circ} \mathrm{C}$ for Volatile Fatty Acids (VFA) and ammonia $\left(\mathrm{NH}_{3}\right)$ analysis. The other part was continued by centrifugation $(10,000 \times g, 15 \mathrm{~min}$, $4^{\circ} \mathrm{C}$ ) and stored at $-20^{\circ} \mathrm{C}$ for determination of enzyme and microbial protein content. On the Tilley and Terry method, both of $48 \mathrm{~h}$ and $72 \mathrm{~h}$ of fermentation samples were centrifuged $\left(3,000 \times g, 15 \mathrm{~min}, 4^{\circ} \mathrm{C}\right)$ and then both residues were used to determine nutrient digestibility including Dry Matter Digestibility (DMD), Organic Matter Digestibility (OMD) and crude fiber digestibility.

Analysis of DM, OM and crude fiber content in residue were determined according to AOAC (2005). Cellulose, hemicelullose and lignin content of feed were conducted according to Van Soest (1963). Enzyme and microbial proteins content were measured by Lowry method (Plummer, 1987). Rumen $\mathrm{NH}_{3}$ concentration was measured using spectrophotometer as described by Chaney and Marbach (1962). Volatile fatty acids concentrations were determined by using Gas Chromatography (GC-2010, Shimadzu, Tokyo, Japan) as described by Flipek and Dvorak (2009). The $\mathrm{CH}_{4}$ and $\mathrm{CO}_{2}$ were estimated according to Church (1988).

\section{Statistical Analysis}

The data were statistically assessed using one way ANOVA. To determine the difference among means, Duncan's multiple range test was subsequently used.

Table 1: Nutrient content of feedstuffs used in the study

\begin{tabular}{|c|c|c|c|}
\hline Feedstuffs $(\%)$ & $\begin{array}{l}\text { Pennisetum purpureum } \\
\text { cv Mott grass }\end{array}$ & Concentrate $^{1}$ & Water spinach \\
\hline Dry matter & 92.93 & 88.87 & 89.42 \\
\hline Organic matter & 83.43 & 89.77 & 84.60 \\
\hline Crude fiber & 31.49 & 17.59 & 21.62 \\
\hline Crude protein & 06.70 & 12.60 & 10.65 \\
\hline Crude fat & 01.35 & 02.66 & 01.86 \\
\hline Ash & 16.57 & 10.23 & 15.40 \\
\hline Nitrogen free extract & 43.89 & 56.92 & 50.47 \\
\hline Total digestible nutrient & 47.16 & 61.85 & 54.28 \\
\hline Hemicellulose & 21.18 & 28.48 & 27.24 \\
\hline Cellulose & 30.70 & 25.35 & 26.88 \\
\hline Lignin & 12.67 & 11.47 & 12.22 \\
\hline
\end{tabular}

${ }^{1}$ Concentrate consisted of corn meal 17.5 , rice by product $5 \%$, corn gluten fat $6.5 \%$, copra $7.5 \%$, palm kernel meal $10 \%$, bran $5 \%$, cassava by product $5 \%$, tapioca by product $15 \%$, rice bran $7.5 \%$, peanut hulls $5 \%$, cassava hulls $5 \%$, soybean hulls $7 \%$, molasses $2.5 \%$, mineral mixture $1 \%$ 
Table 2: Feed ingredient and nutrient composition of dietary treatments

\begin{tabular}{|c|c|c|c|c|}
\hline Feedstuffs & $\mathrm{T} 1$ & $\mathrm{~T} 2$ & $\mathrm{~T} 3$ & $\mathrm{~T} 4$ \\
\hline \multicolumn{5}{|l|}{ Formulation (\%) } \\
\hline Pennisetum purpureum cv Mott grass & 60.00 & 40.00 & 20.00 & 0.00 \\
\hline Water spinach & 0.00 & 20.00 & 40.00 & 60.00 \\
\hline Concentrate & 40.00 & 40.00 & 40.00 & 40.00 \\
\hline Total & 100.00 & 100.00 & 100.00 & 100.00 \\
\hline \multicolumn{5}{|l|}{ Nutrient composition $(\%)$} \\
\hline Dry matter & 90.74 & 90.39 & 90.13 & 88.08 \\
\hline Organic matter & 86.27 & 87.91 & 89.94 & 89.23 \\
\hline Crude protein & 13.72 & 14.36 & 15.06 & 15.04 \\
\hline Crude fat & 2.14 & 2.02 & 1.87 & 2.18 \\
\hline Crude fibre & 21.43 & 22.03 & 21.29 & 20.97 \\
\hline Ash & 13.73 & 12.09 & 10.06 & 10.77 \\
\hline Hemicellulose & 19.77 & 22.86 & 24.04 & 26.02 \\
\hline Cellulose & 18.60 & 23.83 & 28.15 & 31.23 \\
\hline Lignin & 12.48 & 10.55 & 11.10 & 11.77 \\
\hline
\end{tabular}

T1: Control or pelleted feed containing no water spinach, T2: Pelleted feed containing 20\% of water spinach, T3: Pelleted feed containing $40 \%$ of water spinach, T4: Pelleted feed containing $60 \%$ of water spinach.

\section{Results}

The results of in vitro fermentability of pelleted feed with water spinach are shown in Table 3. The inclusion of pelleted water spinach into pelleted diets did not affect $(P>0.05) \mathrm{pH}$, ammonia, protein enzyme and microbial protein. However, the incorporation of water spinach resulted in significant effects on the decrease in total production of VFA, acetic acid, propionate and butyrate, with the lowest levels were at T4 group. The ratio of acetate to propionate increased $(P<0.05)$ with the increased levels of water spinach in the pelleted feed. Methane and $\mathrm{CO}_{2}$ production decreased $(P<0.05)$ with water spinach incorporation in the pelleted feed.

The inclusion of $60 \%$ (T4) water spinach reduced $(P<0.05)$ methane and $\mathrm{CO}_{2}$ productions until $34 \%$ and $36 \%$, respectively.

The results of in vitro digestibility of pelleted water spinach utilization as a fiber source in diets are shown in Table 4. Organic matter digestibility increased $(P<0.05)$ with the increased levels of water spinach in the pelleted feed at $48 \mathrm{~h}$. On the $72 \mathrm{~h}$, the increasing levels of water spinach increased the digestibility of dry matter $(P<0.05)$ and organic matter $(P=0.05)$ of the pelleted feed.

\section{Discussion}

The incorporation of water spinach as the source of fiber in the pelleted feed did not impact the $\mathrm{pH}$, ammonia, enzyme protein and microbial protein. This finding was in accordance with a study conducted by Al-Arif et al. (2017); Li et al. (2003); Xu et al. (2014). Zhang et al. (2019) reported that rumen $\mathrm{pH}$ is highly dependent on feed fermentation and its physical form. Pelleted feed was proved to be able to maintain acid base status without causing acidosis in the rumen. Parish and Rhinehart (2018) explained that feed with high fiber would stimulate rumination process and saliva production playing a role for maintaining rumen $\mathrm{pH}$. Owens and Zinn (1988); Karsli and Russel (2001) found that protein contained in feed was related to ammonia level in rumen. Protein would be deaminated in rumen to produce ammonia, which is an important compound for the synthesis of microbial protein.

It was shown in this study that the increased levels of water spinach were attributed to the decreased levels of VFA production. The latter condition seemed to be associated with the increased levels of cellulose, hemicellulose and lignin in the pelleted feed containing water spinach (Table 2).

Previously, Nathani et al. (2015) and Li et al. (2003) reported that high fiber content in the diets resulted in low concentration of VFA. Cellulose and hemicellulose were structural carbohydrate which are difficult to degrade and take longer time for being used as VFA production substrate. McDonald et al. (2011) stated that the high cellulose and hemicellulose are commonly found in mature forage, the older the forage, the higher the cellulose and hemicellulose content. Jayanegara et al. (2019) and Aderao et al. (2018) suggested the high fiber content (neutral detergent fiber and acid detergent fiber) will reduce VFA production. However, VFA production, as an indicator of energy availability for ruminant, was not different between pelleted feed without water spinach and pelleted feed containing $20 \%$ water spinach. Therefore, this can be inferred that fermentation activity in control feed and pelleted feed containing $20 \%$ water spinach were higher than other treatment (Table 3). 
Table 3: In vitro fermentability of pelleted feed containing water spinach

\begin{tabular}{lllllll}
\hline Parameter & $\mathrm{T} 1$ & $\mathrm{~T} 2$ & $\mathrm{~T} 3$ & $\mathrm{~T} 4$ & SEM & P value \\
\hline $\mathrm{Ph}$ & 6.72 & 6.71 & 6.73 & 6.71 & 0.01 & 0.68 \\
$\mathrm{NH}_{3}, \mathrm{mg} / \mathrm{dl}$ & 18.33 & 17.77 & 18.18 & 17.99 & 0.35 & 0.96 \\
Protein enzyme, $\mathrm{mg} / \mathrm{mL}$ & 0.83 & 0.83 & 0.72 & 0.70 & 0.02 & 0.07 \\
Protein microbial, mg/mL & 160.72 & 169.12 & 166.91 & 154.00 & 2.63 & 0.17 \\
VFA, Mm & $32.13^{\mathrm{a}}$ & $29.63^{\mathrm{ab}}$ & $25.78^{\mathrm{b}}$ & $20.25^{\mathrm{c}}$ & 1.24 & $<0.01$ \\
Acetate, Mm & $22.04^{\mathrm{a}}$ & $20.23^{\mathrm{ab}}$ & $18.06^{\mathrm{b}}$ & $14.09^{\mathrm{c}}$ & 0.83 & $<0.01$ \\
Propionate, Mm & $8.07^{\mathrm{a}}$ & $7.52^{\mathrm{a}}$ & $5.90^{\mathrm{b}}$ & $4.75^{\mathrm{b}}$ & 0.35 & $<0.01$ \\
Butyrate, Mm & $2.01^{\mathrm{a}}$ & $1.88^{\mathrm{a}}$ & $1.82^{\mathrm{a}}$ & $1.41^{\mathrm{b}}$ & 0.07 & 0.01 \\
Acetate to propionate ratio & $2.74^{\mathrm{c}}$ & $2.69^{\mathrm{c}}$ & $3.06^{\mathrm{a}}$ & $2.97^{\mathrm{b}}$ & 0.37 & $<0.01$ \\
$\mathrm{CH}_{4}, \mathrm{Mm}$ & $10.01^{\mathrm{a}}$ & $9.18^{\mathrm{ab}}$ & $8.46^{\mathrm{b}}$ & $6.56^{\mathrm{c}}$ & 0.36 & 0.01 \\
$\mathrm{CO}_{2}, \mathrm{Mm}$ & $16.06^{\mathrm{a}}$ & $14.82^{\mathrm{ab}}$ & $13.23^{\mathrm{b}}$ & $10.35^{\mathrm{c}}$ & 0.60 & $<0.01$ \\
\hline $\mathrm{a} \mathrm{b}, \mathrm{c} D i f f$ & & & &
\end{tabular}

${ }_{\mathrm{a}, \mathrm{b}, \mathrm{c}}$ Different superscripts in the same row show significant different among treatments

T1: Control or pelleted feed containing no water spinach, T2: Pelleted feed containing $20 \%$ of water spinach, T3: Pelleted feed containing $40 \%$ of water spinach, T4: Pelleted feed containing $60 \%$ of water spinach

Table 4: In vitro digestibility of pelleted feed containing water spinach

\begin{tabular}{lllllll}
\hline Parameter & T1 & T2 & T3 & T4 & SEM & P value \\
\hline 48 h,\% & & & & & & \\
Dry matter & 69.14 & 66.27 & 69.14 & 69.44 & 0.76 & 0.45 \\
Organic matter & $67.81^{\mathrm{b}}$ & $74.91^{\mathrm{ab}}$ & $81.67^{\mathrm{a}}$ & $82.01^{\mathrm{a}}$ & 1.38 & 0.01 \\
Crude fiber & 51.48 & 52.25 & 57.89 & 53.63 & 1.03 & 0.11 \\
$72 \mathrm{~h}, \%$ & & & & & & \\
Dry matter & $72.20^{\mathrm{c}}$ & $78.47^{\mathrm{bc}}$ & $85.46^{\mathrm{ab}}$ & $89.99^{\mathrm{a}}$ & 2.36 & 0.01 \\
Organic matter & $74.59^{\mathrm{b}}$ & $77.93^{\mathrm{ab}}$ & $83.47^{\mathrm{a}}$ & $84.77^{\mathrm{a}}$ & 1.38 & 0.05 \\
Crude fiber & 66.09 & 68.48 & 63.48 & 65.50 & 1.70 & 0.16 \\
\hline
\end{tabular}

${ }^{\mathrm{a}, \mathrm{b}, \mathrm{c}}$ Different superscripts in the same row show significant different among treatments

T1: Control or pelleted feed containing no water spinach, T2: Pelleted feed containing $20 \%$ of water spinach, T3: Pelleted feed containing $40 \%$ of water spinach, T4: Pelleted feed containing $60 \%$ of water spinach.

Acetate production decreased with increasing proportion of water spinach in pelleted feed. This result was not consistent with the finding of Harahap et al. (2019) and Maktabi et al. (2016), who reported that feed with high neutral detergent fiber content will impact to enhance acetate concentration in rumen. This is may indicate that high cellulose content take longer time for microbe to convert substrate into VFA in the end of fermentation process. This phenomenon was supported by the lower VFA concentration in pelleted feed containing water spinach than that in control pelleted feed. In addition, Hasanah et al. (2019) reported that potential of degraded fraction in feed supplemented with 0 or $20 \%$ water spinach was higher compared to $40 \%$ and $60 \%$ water spinach inclusion in feed. Indeed, the lowest acetate concentration on pelleted feed containing $60 \%$ water spinach was followed by the increasing acetate to propionate ratio and decrease methane and $\mathrm{CO}_{2}$ production. Methane is the result of acetate fermentation in rumen. This is because hydrogen will also be produced in the process of forming acetate. Hydrogen is the main component of producing methane other than carbon (Lan and Yang, 2018; Hook et al., 2010). These conditions have an impact on reduction of methane in pelleted feed containing $60 \%$ water spinach. With regard to $\mathrm{CO}_{2}$, the production of this gas decreased with the increased levels of water spinach in pelleted feed.
In this study, OM digestibility of the pelleted feed containing different levels of water spinach was not different although control feed had lower OM digestibility compared to pelleted feed containing $40 \%$ and $60 \%$ water spinach. Increasing OM digestibility in water spinach supplemented pelleted feed incubated at $48 \mathrm{~h}$ indicated that more feed was fermented by the microbes. This may eventually increase the microbial population in the rumen. In general, the process of rumen microbial synthesis requires carbohydrate as energy and nitrogen in the form of $\mathrm{NH}_{3}$. McDonald et al. (2011) and Klein (2019) stated that the number of microbes that can be synthesized in rumen is limited by the amount of energy and efficiency in the use of energy by the microbes as well as the adequacy of $\mathrm{NH}_{3}$ as a source of protein. Meanwhile $\mathrm{NH}_{3}$ concentration among the treatment groups was not different (Table 3). This may indicate, therefore, that the carbohydrate, as energy source for microbial synthesize, was utilized better when including water spinach. Harahap et al. (2019) suggested that better synchronization between ruminal $\mathrm{NH}_{3}$ release and carbohydrate availability are necessary to support rumen microbial synthesize. Note that decreasing of microbial synthesis will affect the degradation of feed in rumen. On the other word, increasing DM and OM digestibility at $72 \mathrm{~h}$ was caused by the chloride acid $(\mathrm{HCl})$ and pepsin enzyme supplementation following the ruminal fermentation 
process. This was supported by McDonald et al. (2011) that post-rumen digestibility was accelerated by the presences of $\mathrm{HCl}$ and pepsin enzymes in abomasum.

\section{Conclusion}

Water spinach may replace the portion of Pennicetum purpureum at a level of $20 \%$ in pellet feed because resulted in highest OMD and VFA production and also lowest ratio of acetate to propionate.

\section{Acknowledgement}

The author would like to thanks to Animal Science student of Gadjah Mada University who helped author to conduct the study. The author sincerely thanks Prof. A. Purnomoadi, Dr. R. Adiwinarti and Dr. Sugiharto, who guide the author during the study.

\section{Author's Contributions}

All authors took parts in the preparation, development and publication of this manuscript.

\section{Ethics}

The author declares that there are no ethical issues related to this study.

\section{References}

Aderao, G.N., A. Sahoo, R.S. Bhatt, P.K. Kumawat and L. Soni, 2018. In vitro rumen fermentation kinetics, metabolite production, methane and substrate degradability of polyphenol rich plant leaves and their component complete feed blocks. J. Anim. Sci. Technol., 60: 1-9. DOI: 10.1186/s40781-018-0184-6

Al-Arif, M.A., L.T. Suwanti, A.T.S. Estoepangestie and M. Lamid, 2017. The nutrient contents, dry matter digestibility, organic matter digestibility, total digestible nutrient and $\mathrm{NH}_{3}$ rumen production of three kinds of cattle feeding models. KnE Life Sci. DOI: $10.18502 / \mathrm{kls} . v 3 \mathrm{i} 6.1142$

AOAC, 2005. Official Method of Analysis of the Association of Official Analitycal Chemist. 18th Edn., The Association, ISBN-10: 0935584676.

Bertipaglia, L.M.A., M. Fondevila, H. Van Laar and C. Castrillo, 2010. Effect of pelleting and pellet size of a concentrate for intensively reared beef cattle on in vitro fermentation by two different approaches. Animal Feed Sci. Technol., 159: 88-95. DOI:10.1016/j.anifeedsci.2010.05.010

Chaney, A.L. and E.P. Marbach, 1962. Modified reagents for determination of urea and ammonia. Clin. Chem., 8: 130-132.
Church, D.C., 1988. Digestive Physiology and Nutrition. 2nd Edn., O and B Books, pp: 416.

Flipek, J. and R. Dvorak, 2009. Determination of the volatile fatty acid content in the rumen liquid: Comparison of gas chromatography and capillary isotachophoresis. Acta Vet. Brno., 78: 627-633. DOI: $10.2754 / \mathrm{avb} 200978040627$

Harahap, M.A., L.K. Nuswantara, F. Wahyono, E. Pangestu and J. Achmadi, 2019. In vitro rumen fermentability of urea-limestone mixture combined with different sources of non-fiber carbohydrate. Livestock Res. Rural Dev. 31(5).

Hasanah, H., J. Achmadi, E. Pangestu and A. Agus, 2019. Evaluation of water spinach (Ipomea aquatica) as forage substitution on in vitro gas production, digestibility and kinetic fermentation. Proceedings of the 5th International Conference on Agricultural and Biological Science, Jul. 21-24, IOP, pp: 346. DOI: $10.1088 / 1755-1315 / 346 / 1 / 012069$

Hook, S.E., A.D. Wright and B.W. McBride, 2010. Methanogens: Methane producers of the rumen and mitigation strategies. Archae. DOI: $10.1155 / 2010 / 945785$

Jayanegara, A., A. Yaman and L. Khotijah, 2019. Reduction of proteolysis of high protein silage from Moringa and Indigofera leaves by addition of tannin extract. Vet. World, 12: 211-217. DOI: $10.14202 /$ vetworld

Karsli, M.A. and J. Russel, 2001. Effect of some dietary factors on ruminal microbial protein synthesis. Turkish J. Vet. Anim. Sci., 25: 681-686.

Khamparn, P. and T.R. Preston, 2006. Effect of a supplement of fresh water spinach (Ipomoea aquatica) on feed intake and digestibility in goats fed a basal diet of cassava foliage. Livestock Res. Rural Dev.

Klein, G.B., 2019. Cunningham's Textbook of Veterinary Physiology. 6th Edn., Health Sciences, ISBN-10: 0323553605, pp: 656.

Lan, W. and C. Yang, 2018. Ruminal methane production: Associated microorganisms and the potential of applying hydrogen-utilizing bacteria for mitigation. Sci. Total Environ., 654: 1270-1283. DOI: $10.1016 /$ j.scitotenv.2018.11.180

Li, D.Y., S.L. Sang, N.J. Choi, S.Y. Lee and H.G. Sung et al., 2003. Effect of feeding system on rumen fermentation parameters and nutrient digestibility in Holstein steers. AsianAustralasian J. Anim. Sci., 16: 1482-1486. DOI: 10.5713 /ajas.2003.1482

Maktabi, H., E. Ghasemi and M. Khorvash, 2016. Effects of substituting grain with forage or nonforage fiber source on growth performance, rumen fermentation and chewing activity of dairy calves. Anim. Feed Sci. Technol., 221: 70-78. DOI: 10.1016/J.ANIFEEDSCI.2016.08.024 
McDonald, P., R.A. Edwards, J.F.D. Greenhalgh, C.A. Morgan and L.A. Sinclair et al., 2011. Animal Nutrition. 7th Edn., Pearson, Canada.

Menke, H.H. and H. Steingass, 1988. Estimation of the energetic feed value obtained from chemical analysis and in vitro gas production using rumen fluid. J. Anim. Res. Dev., 28: 7-55.

Nathani, N.M., A.K. Patel, C.S. Mootapally, B. Reddy and S.V. Shah et al., 2015. Effect of roughage on rumen microbiota composition in the efficient feed converter and sturdy Indian Jaffrabadi buffalo (Bubalus bubalis). BMC Genom., 16: 1116-1116. DOI: $10.1186 / \mathrm{s} 12864-015-2340-4$

Opene, A.O., C.U. Ogunka-Nnoka and A.A. Uwakwe, 2018. Comparative study on the nutrient composition and in-vitro antioxidant properties of leaves and stems of Ipomoea involucrata. Int. J. Agric. Innovat. Res., 7: 272-279.

Owens, F.N. and R. Zinn, 1988. Protein Metabolism of Ruminant Animals. In: The Ruminant Animal Digestive Physiology and Nutrition, Church, D.C. (Ed), Reston Book Prentice Hall, Englewood Cliffs, New Jersey, pp: 227-249.

Oyaniran, D.K., V.O.A. Ojo, R.Y. Aderinboye, B.A. Bakare and J.A. Olanite, 2018. Effect of pelleting on nutritive quality of forage legumes. Livestock Res. Rural Dev.

Parish, J.A. and J.D. Rhinehart, 2018. Fiber in Beef Cattle Diets. Mississippi State University. United States.

Plummer, D.T., 1987. An Introduction to Practical Biochemistry. 3rd Edn., McGraw-Hill, ISBN-10: 0070840741, pp: 362.
SI, 2017. Statistics of seasonal vegetable and fruit plants, Indonesia. Statistics Indonesia.

Silivong, P. and T.R. Preston, 2016. Supplements of water spinach (Ipomoea aquatica) and biochar improved feed intake, digestibility, $\mathrm{N}$ retention and growth performance of goats fed foliage of Bauhinia acuminata as the basal diet. Livestock Res. Rural Dev.

Tilley, J.M.A. and R.A. Terry, 1963. A two-stage technique for the in vitro digestion of forage crops. Grass Forage Sci., 18: 104-111. DOI: $10.1111 / \mathrm{j} .1365-2494.1963 . t b 00335 . x$

Umar, K.J., L.G. Hassan, S.M. Dangoggo and M.J. Ladan, 2007. Nutritional composition of water spinach (Ipomoea aquatica Forsk.) leaves. J. Applied Sci., 7: 803-809. DOI: $10.3923 /$ jas.2007.803.809

Van Soest, P.J., 1963. Use of detergents in the analysis of fibrous feeds. II-A rapid method for the fiber and lignin. Assoc. Official Analy. Chem., 46: 830-832.

Xu, J., Y. Hou, H. Yang, R. Shi and C. Wu et al., 2014. Effects of forage sources on rumen fermentation characteristics, performance and microbial protein synthesis in midlactation cows. Asian-Australasian J. Anim. Sci., 27: 667-673. DOI: 10.5713/ajas.2013.13604

Zhang, C., M.M. Li, O. Al-Marashdeh, L.P. Gan and C.Y. Zhang et al., 2019. Performance, rumen fermentation and gastrointestinal microflora of lambs fed pelleted or unpelleted total mixed ration. Anim. Feed Sci. Technol., 253: 22-31. 